\title{
Impact of Global Capitalism on the Environment of Developing Economies: The Case of Nigeria
}

\author{
God'stime Osariyekemwen Igiebor*
}

\begin{abstract}
Globalization may have generated gains in some countries of the world; it is nevertheless associated with increased insolvency, inequalities, work insecurities, weak institutions, and corrosion of established values. Against this backdrop, the paper takes a cursory look at the global flow of capital and how it has impacted the Nigerian economy. It posit that the system of global governance is not consistent with the objective of the domestic economy given that globalization results in the weakening of state capacity through dominance of the transnational flow of capital and investment. Hence, the transnational network of production and services is orchestrated beyond the regulation of policies of domestic countries. Consequently this paper offers recommendations on how the Nigerian economy should develop in order to keep pace with globalization. These include developing local technology, promoting domestic industry and manufacture of goods for exports as well as managing domestic affairs free from extraneous foreign intrusion.
\end{abstract}

Keywords: globalization, capital flow, economy, dependency, development

\section{INTRODUCTION}

The changing order in the present world system resulting from globalization has engendered public debate among scholars worldwide regarding "the wide difference amongst nations in terms of natural endowments, divergence in skills acquisition, relative widening gap of inequality, poverty, socio-economic and political instability,

* God'stime Osariyekemwen Igiebor is a lecturer, Department of Political Science and Public Administration, University of Benin, Benin City, Nigeria. E-mail: goddyigieb@yahoo.com, osariyeketime@gmail.com. He holds a first class BA in public administration and an MSc in comparative politics and development studies from the University of Benin. His research interests lie in the areas of violence, political behavior, political economy, and development studies.

Manuscript received October 22, 2014; out for review October 31, 2014; review completed December 13, 2014; accepted December 16, 2014.

The Korean Journal of Policy Studies, Vol. 29, No. 3 (2014), pp. 79-100.

(C) 2014 by the GSPA, Seoul National University 
etc. Nation-states must on the premise of these differentials, co-exist with one and another so as to ensure global balance of ideals, knowledge and capacity building for overall global sustainability" (Esidene and Hafsat, 2012, p. 2). Attempting to further this effort, the advanced economies such as those of Europe and America extended their hands of partnership to the third world countries, which include states in Africa, Asia, and Latin America (Esidene \& Hafsat, 2012).

The impact of globalization is so widespread that no nation can afford to sit back if it is to maintain an acceptable level of growth and development (Peter, 2002). The world has become a global village where advanced information technology has permeated zones that were hitherto inaccessible. This new epoch presents new challenges with its attendant global problems. Dani (1999), Salimono (1999), and David (1999) aver that globalization opens up opportunities, while Garry (1998) and Awake (2002) express doubts about its benefits.

Advances in communication technology and the deregulation of financial markets have intensified global capital flow. The opening up of domestic markets to competition, the privatization of industry, and the retreat of the state from economic management are all features of the current global order. However, this process has engendered increasing inequality among nations (Rapley, 2004; Onwuka \& Eguavoen, 2007). Globalization has mainly been driven by the interests and desires of the industrialized world, and inequality in many parts of the world has spawned seeds of frustration and unrest (Grieco \& Holmes, 1999).

The premise of this paper is that globalization has given rise to a form of inequality and marginalization; its nature, character, and purpose does not present favorable benefits for developing countries. Examining the effect of global capital flow on the economy of Nigeria, the paper seeks to offer policy advice on how Nigeria can make use of the opportunities that globalization presents to its economic advantage. The article is structured into six parts. Following this introduction is a segment that briefly highlights the history of globalization phenomenon. The third section examines the analytical utility of the concepts of globalization, dependency, and world systems. The fourth considers the benefits and risks that a globalized economy introduces. The fifth considers Nigeria's economic environment in relation to globalization. The sixth and final section offers a number of policy recommendations.

\section{GLOBALIZATION: A BRIEF BACKGROUND}

The concept of globalization emerged over six centuries ago. Discoveries and development in the technological and scientific fields of human endeavor have had an 
impact on the evolution of the concept. Marine transportation, railways, and airplanes, along with the internet and e-mail technologies, all of which guarantee efficient movement of goods and services, are major examples of these advancements (Held et al., 1999; Hagher, 2002). These developments in Western technologies opened up Africa to colonialism, which had dire effects. The colonialists established a system of government that distorted the organized procedures, principles, and values of the African continent, which resulted in the exploitation of human and material resources to an unquantifiable degree (Hagher, 2002).

The end of Second World War brought a growing globalization, christened "internationalism," that came with the birth of the United Nations (UN) in 1945. The main objective of the UN was to seek a just resolution to the war and to encourage world peace through cooperative efforts. The UN introduced the world to the global village concept. Global connections exploded during the second half of the twentieth century in the form of global companies, global governance agencies, transborder social movements, global finance, global production processes and global markets, and so forth (Egonmwan, 1991; Scholte, 2000; Wallerstein, 2003).

\section{THE CONCEPTUAL GROUNDS OF GLOBALIZATION, DEPENDENCY, AND WORLD SYSTEMS}

"Globalization" is the term employed to explain the increasing interdependence of people and countries the world over. This interdependence influences the political, socioeconomic, and cultural relations of countries across the globe. Abimbola and Aremo (2002) view globalization as the barrier-free undertaking of economic activities across national borders. These activities include trade, production, manufacturing, capital, investment, and so on. Globalization is the broadening and depending linkages among national economies, giving rise to an international market for goods and services, principally capital (Ohiorhenuan, 1998; Nayyar, 2006). Indeed, globalization seeks to eradicate all national blockades so as to allow easy movement of international capital, a goal that is facilitated by transformations in information technology (Tandon 1998b). Globalization of the world economy can thus be seen as the integration of economies throughout the world by means of trade, financial flows, exchange of information technology, and the movement of people. Cohn's (2005) view of globalization as a process that involves the broadening (the geographic extension of linkages to almost all major societies and states) and deepening (increase in the frequency and intensity of interactions) of interdependence among societies and states throughout the world can be seen as a corollary to the internationalization of capital. In terms of people's 
daily activities, globalization means that residents of another country are now more likely to consume products of other countries, interact with people in other countries through the telephone or e-mail, and visit and know more about other countries.

Globalization certainly has become an extremely controversial issue. Supporters of globalization, sometimes called globalists or hyperglobalists, contend that capitalism is inclined toward general prosperity and that globalization creates more opportunities for people in more countries to enjoy the benefits accruing from it (Heywood, 2007). Opponents of globalization, on the other hand, tend to link capitalism with inequality and exploitation and contend that global capitalism will invariably result in new forms of desolation and injustice. In this vein, the skeptics have highlighted the links between capitalism and imperialism in the early twentieth century. In addition, the skeptics point out that despite a profound growth in world trade from the late nineteenth century onward the overwhelming bulk of economic activity still occurs within and not across national boundaries, which indicates that national economies are not as irrelevant as globalization theorists generally suggest. From this standpoint, globalization is often seen less as a revolutionary economic or technological force and more as an ideological device, employed by politicians and theorists who support neoliberal economies and wish to advance corporate interests (Hirst \& Thompson, 1999). However, the transformationalists aver that globalization produces new economic, political and social circumstances that, however unevenly, are helping to transform state powers and the framework in which states operate. They do not predict the outcome because they acknowledge that it is uncertain; rather they argue that politics is no longer and can no longer merely be based on nation-states (Fukuyama, 1989, 1992).

The most intense debate on globalization however, concerns its implications for equality and poverty. Critics of globalization have drawn attention to the emergence of novel and extremely embedded models of inequality that expose globalization as a game of winners and losers. The winners are notably identified as multinational corporations and industrially advanced states like the Unites States, whose economy was well established before the 1980s, while the losers are in developing countries like Nigeria, where wages are low, regulations are weak or nonexistent, and where production is increasingly orientated toward global markets rather than domestic needs. Living standards have fallen in the poorest parts of the world, mostly in sub-Saharan Africa, where $40 \%$ of people live below the poverty line (Heywood, 2007). Globalists, however, point out that although the rich may indeed have gotten richer, the poor are now also, in most cases, less poor. From the perspective of liberal pluralism, a global economy is to be genially embraced, since free trade enables each country to specialize in the production of those goods and services that it is best suited to produce, which produces mutual benefits for all. Hence, those countries that fail to benefit from globalization in 
this view are those that remain outside it (Klein, 2000; Heywood, 2007). Thus, globalization can be understood as producing benefits and losses, both between and within countries (IMF, 2002; World Bank, 2002).

Globalization has also been criticized because of its tendency to encourage risky behavior and give rise to uncertainty and instability (Beck, 1992). Dani (1999) avers that globalization is associated with instability in output and employment and therefore could give rise to industrial conflicts that in turn could put strain on the structure of the society when job security is threatened. Globalists certainly recognize the dynamism inherent in any competitive market structure; however, in line with the principles of classical economics, they argue that markets tend toward long-term equilibrium in which supply ultimately matches demand. On this view, the uncertainty and insecurity connected with the emergence of a global economy are likely to disappear as pattern of economic activity stabilizes (Heywood, 2007).

The different perspectives on globalization notwithstanding, a common strand runs through most of them, which is that globalization describes a phenomenon of growing interdependence among people worldwide; in activities among nations, governments, business, institutions, communities, families, and individuals. It promotes the development of a global attitude and consciousness of a "borderless world" by using information to build partnerships and encourage greater financial and economic integration (Obadan, 2008). Globalization is often portrayed solely as an economic phenomenon. Much is made of transnational corporations, whose massive operations extend across national borders, influencing global production processes, and the international distribution of labor (Ajayi, 2001). Others point to the electronic integration of global financial markets and the enormous volume of global capital flows. Still others focus on the unprecedented scope of world trade (Giddens, 2006). While economic forces act as primary element of globalization, it would be overstating the case to imply that they alone create it. It is a multifaceted phenomenon that not only integrates economies worldwide but that impacts religious, environmental, and social spheres (Daouas, 2001; Giddens, 2006). Political, social, cultural, and economic factors all have contributed to its development, which has further been facilitated by the development of information and communication technologies that have expanded the scope of interaction among people the world over (Mittelman, 2006).

The rationale for adopting structural theories of dependency and world systems in analyzing the economies of developing societies stems from the fact that most third world countries like Nigeria were victims of the historical hegemony and exploitation of colonialism, which has metamorphosed into globalization. These theories paint a vivid picture of how colonialism as well as contemporary international power relations have led to the underdevelopment of these regions, suggesting that international 
inequalities are socially structured and that hierarchy is a central feature of the global system of societies (O'Rourke \& Williamson 2000). Therefore, these theoretical perspectives serve as strategies for explaining social change that centers on intersocietal systems. Networks connected to trade, information flows, associations, and movements have woven polities and cultures together since the beginning of human social development.

The modern world system can thus be perceived structurally as a formation of strata made up of economically, culturally, and militarily dominant core societies that compete with one another and also with dependent peripheral and semiperipheral regions (McMichael, 2000). Dependency theory argues that the rich nations of the world need a peripheral group of poorer states to sustain their rich status. It views nations of the word as divided into a core of wealthy nations that control a periphery of poor nations, whose key function is to provide cheap labor and raw materials to the core. It holds that the benefit of this arrangement accrues almost wholly to the rich nations, which become richer and better developed. The poor nations, by contrast, whose surpluses are continually sapped away to the core do not experience growth (Chilcote, 1984). Poor countries export primary commodities to the rich countries that in turn manufacture products out of these commodities and sell them back to the poorer countries. Manufacturing a usable product will eventually cost more than the primary products used to create those products. Thus, poorer countries will never earn enough from their export earnings to pay for their imports.

Most dependency theorists consider international capitalism to be the driving force behind dependency relationships. Andre Gunder Frank, one of the foremost dependency theorists, is quite lucid on this point:

Historical research demonstrates that contemporary underdevelopment is in large part the historical product of past and continuing economic and other relations between the satellite underdeveloped and the now developed metropolitan countries. Furthermore, these relations are an essential part of the capitalist system on a world scale as a whole. (1970, p. 4)

Dependency theorists contend that the core relationship between societies is an exploitative one that concomitantly produces wealth at one of its poles, the metropolis (Frank, 1969), or the center (Galtung, 1972), and poverty at the other pole, the satellite (Frank), or the periphery (Galtung, 1972; Amin, 1971). According to Frank and Amin, such developing, underdeveloping, or exploitative relations not only circumscribe nation-states but also subnational or cross-national regions. Arghiri (1972) represents these exploitative relationships in terms of a world order composed of hierarchically 
arranged rich and poor countries, each exploiting the other(s) lower on the ladder.

The fundamental message of the dependency school is that the development of the metropolis results from the active underdevelopment of the nonmetropolis communities; the significance of dependency theory lies in the recognition that development and underdevelopment have taken place in the context of the growth of capitalism as a world system. The approach valuably analyzes relationships between nations and considers both development and underdevelopment to be historically observable consequences resulting from those relationships.

Dependency, therefore, refers to a situation in which certain economies of the world are conditioned by the development of another economy to which the former is subject, which can have a negative consequences for the subject nation's domestic economy. The theory holds that for developing nations to achieve an adequate growth level, they must break their linkage with developed nations and institute and pursue internal mechanisms for development. One type of policy crafted from this proposition was import substitution industrialization.

World systems theory arose in reaction to criticisms of dependency theory. In world systems theory, the division between the periphery and center is replaced with a trimodal system consisting of the core, semiperiphery, and the periphery in which the core exploits both the semiperiphery and the periphery while the semiperiphery exploits the periphery (Wallerstein, 2005; Lechner, 2001). The most well- known version of world systems theory was developed by Immanuel Wallerstein, a U.S. sociologist, historical social scientist, and world systems analyst, in the 1970s and 1980s. World systems analysis asserts that the world system rather than nation-states should be the primary (but not exclusive) unit of social analysis.

There exists a basic and institutionally stabilized division of labor between the core and periphery. While the core has a high level of technological development and manufactures complex products, the function of the periphery is to provide raw materials, agricultural crops, and cheap labor for the expanding agents of the core. Economic exchange between core and periphery takes place on disparate terms; the periphery is constrained to sell its products at low prices but has to purchase the core's manufactured goods at comparatively high price. With these developments, nation-states lose power and influence and even sovereignty because they are constrained (by forces and economic interest) to tailor their policies to the needs of mobile capital, which has consequences for the viability of social democracy or the welfare state to the extent that they are at odds with the needs of business interests (Gray, 1996; Strange, 1996; Cerny \& Evans, 2004; Crouch, 2004).

The forces that control the globalization process are capitalist, and their agenda is to promote economic liberalization and enthrone capitalism as a global ideology 
(Babawale, 2007). Culturally, critics suggest that globalization leads to the decline of national cultures and to homogenized global cultures. National distinctions become less noticeable as people consume culture from around the world rather than exclusively from their own nation (Tomlinson, 1999; Mackay, 2000; Sklair, 2002; Nederveen, 2004). This is further promoted by global electronic communications, such as the internet and globalized TV broadcasts, and by migration and tourism (Scholte, 2005). Politically, states are superseded by international organizations like the UN and IMF (International Monetary Fund), by global social movements, or even by a global civil society (Gill, 2000; Keane, 2003). Thus, economically, politically and culturally, global forces are replacing nations as the main sources of economy, sovereignty, and identity (Beck, 2006; Urry, 2000).

Liberal policies and integration of countries into the global economy may have positively impacted on some regions of the world, for instance, China, India, and other parts of Asia. In these places, though, protectionism and state intervention may account for part of the success story. But many countries in Africa have, by contrast, fallen prey to greater inequality and poverty and are increasingly less likely to stand any chance in the competitive and unrestricted global economy that some have advocated as the solution to their problems (Rodrik, 2000; Wolf \& Wade, 2002; Kaplinsky, 2005).

Globalization may have a discriminating effect depending on type (economic, cultural, or political) or location where it is experienced, but the inequality instigated by it may have no clear geographical demarcations because, for instance, the marginalized may live in the same cities as the elites (Hoogvelt, 2001; Bauman 1998; Halsall, 1997). Dependency and world system theories describe well the methods by which Nigerian economic resources have been exploited by the advanced economies via the instrumentality of globalization (global financing, aids, lopsided trade, etc.).

\section{GLOBALIZATION: BENEFITS AND RISKS}

Globalization has reduced barriers in international trade and has thus opened the door for export-led growth (Salimono, 1999). Since globalization entails trade liberalization, it is therefore imperative that there is free and unrestricted movement of trade, capital, and investments across international borders (Oputa, 1996; Salimono, 1999). The advantage here is that globalization enables Nigeria to export and import goods and to move capital, and investments without restriction. Salimono (1999) opines that for smalland medium-sized economies with a limited internal market to advance economically, the potentials for growth lies to a large extent, on production oriented toward the 
international market. He points to countries like China, Chile, and Bostwana and areas like the Ivory Coast, whose economies over the last three decades have grown at very rapid rate of $7 \%$ to $8 \%$ or more, expanding at a faster rate than the GDP. Globalization thus can help promote a rapid growth in output that is capable of increasing national income, enhancing the standard of living of developing countries, and eradicating poverty. A dramatic increase in prosperity came with the advent of globalization, particularly in countries as South Korea, India, and South Africa (Salimono, 1999).

Globalization has enriched the world economically, scientifically and culturally (Awake, 2002), and has opened economies to a wider range of consumption of goods and new and expanding technologies. Through the internet, globalization promotes access to ideas about new technologies and best practices in all areas of human engagement. For instance, new designs, production technology, new managerial practices, and so forth are made available to people, thereby enabling them to modify their existing practices and culture where necessary.

Peter (2002) asserts that globalization creates global marketplace, an avenue through which developments in communication technology can be accessed by virtually any one from any location. It thus grants access to a world of business opportunities and to markets hitherto obscured. According to Akinboye (2008), information and communications technology has radically transformed the world; the interconnectivity it makes possible is such that what affects one country can be seen and felt across the world and can even affect or influence other countries that are thousands of miles away.

Other benefits of globalization according to Onwuka and Eguavoen (2007) include exposure to new ideas and products, greater specialization and expanded opportunities for mergers and acquisitions that increases competition and efficiency in the utilization of resources and brings major improvements in social development and human welfare.

Indubitably, increased trade and investment flows help countries to develop more quickly, as trade generates income and investment flows enable them to increase their stock of productive capital without compromising their level of consumption. When such flows are in the form of foreign direct investment (FDI), they often improve access to international best practices in terms of managerial, marketing, and technical know-how, skills acquisition, and institutional deepening (Onwuka \& Eguavoen, 2007). Moreover, the intangible assets of transnational corporations such as knowledge, technology, management know-how, and market access not only provide essential links between national economies but also serve as catalysts for investment and competition as well as as complements to domestic development resources in recipient countries (UNCTAD, 2001b).

However lofty these benefits may appear, there is apprehension that globalization puts strain on countries integrated into the economy. Awake (2002) expresses perhaps 
the greatest concern over the increasing gap between the haves and the have-nots. While global wealth has increased, it has been concentrated in the hands of few privileged individuals and a few economies. The net worth of the 200 richest people on earth now exceeds the combined income of $40 \%$ of the people who live on the planet. Moreover, while wages continue to rise in wealthy countries, over 80 impoverished countries continue to witness a decline in average income. Nigeria is said to be among these 80 countries.

\section{GLOBAL ECONOMIC ANALYSIS: NIGERIA IN PERSPECTIVE}

Since 1990, greater economic cooperation has increased the ratio of the growth of world export volume to the growth of gross world product to a range of 2.5-3 from an average of below 2 in the 1970s and 1980s (UN, 2001). Transnational corporations with their intensive global integration of production, distribution, and services have encouraged competition and efficiency in the deployment of product resources and key advances in social development and human well-being. Between 1990 and 2001, for example, the stock of outward FDI of transnational corporations increased from \$US1.7 trillion to \$US6.6 trillion, and in 2001 alone, sales totaling \$US19 trillion were more than double the number of world exports (UNCTAD, 2002a). According to the United Nations Conference on Trade and Development (2012), foreign affiliates of transnational corporations in 2011 employed an estimated 69 million workers, who generated US\$28 trillion in sales and US\$7 trillion in value added, up some $9 \%$ from 2010. Transnational corporations have built up record amounts of cash reserves, which so far have not translated into sustained growth in investment. The current cash projection may fuel a future surge in FDI. FDI remains one of the most significant forms of cross-border capital flow into developing countries. In 2012, for example, FDI inflow into developing countries amounted to over US\$790 billion, surpassing by a wide margin the size of inward remittance (US\$406 billion) and official development aid (US\$126 billion) from traditional Organization for Economic Co-operation and Development donors. FDI flows into sub-Saharan Africa have grown nearly sixfold over the past decade. The flows increased from about US\$6.3 billion in 2000 to US $\$ 35$ billion in 2012. While this is still just $2.5 \%$ of total global flows, it represents an unprecedented size of investment capital in most African countries, much larger than remittances or official aid (World Bank, 2014).

The developed countries use their competitive advantage to increase their share of world trade and finance (Khor, 2000; UNCTAD, 2003). Conversely, developing countries are losing out, the victims of imbalances and distortions in the global economy 
(Collier \& Dollar, 2001). As Zuma (2003) observes, uneven distribution of political, economic, and military power has meant that globalization creates immense opportunities for wealth for a minority of the world's population while retarding the advancement of the majority. For example, in 2011, exports and imports for Africa totaled US\$582 billion and US $\$ 569$ billion, respectively, while exports and imports among developing economies totaled US\$18.2 billion and US\$7.3 billion, respectively (UNCTAD, 2013). These figures imply that Africa is expending almost all of its exports earnings on imports in contrast to its counterparts from the developing and developed countries, who have posted a favorable balance of payments. Africa, according to the UNCTAD (2013), remains a marginal player in world trade, accounting for only $2.8 \%$ of world exports (in current U.S. dollars) and $2.5 \%$ of world imports in the decade from 2000 to 2010. The shares of both Africa and sub-Saharan Africa in world exports and imports have fallen significantly over the period from 1970 to 2011. This downward trend can be observed in almost all regions in Africa and almost all African regional economic communities.

Nigeria joined the international market at a competitive disadvantage, having largely a single product based economy, a weak currency, a declining local industrial base. Its economic development has furthermore been destabilized by military dictatorship, political instability, weak leadership, corruption and poor macroeconomic management. Nigeria's former rulers failed to diversify the economy (UNCTAD, 2002a). The economy is overdependent on the capital-intensive oil sector, which constitutes less than $25 \%$ of GDP, despite providing $95 \%$ of foreign exchange earnings and about $65 \%$ of government revenues. The largely subsistence agricultural sector has not been able to match the fast growth in population hence; the country now imports some of its foodstuffs. In 2006, Nigeria successfully convinced the Paris Club to a debt buy back, making cash payment of approximately US $\$ 12$ billion for the bulk of its debt (Okonjo- Iweala, 2007; Chiakwelu, 2008; Wikipedia, 2013).

As a result, the Nigerian economy has been deeply reliant on the West in the form of key globalization agencies such as the IMF, the World Bank, and the World Trade Organization. These three institutions helped shape the current era of globalization. All three institutions trace their origins to the end of the Second World War (19391945), when the United States and Great Britain decided to set up new institutions and rules for the global economy (UNCTAD, 2003). The IMF makes loans available so that countries can maintain the value of their currencies and repay foreign debt. Countries accumulate foreign debt when they buy more from the rest of the world than they sell abroad. They then need to borrow money to make up the difference, which is known as balancing their payments. After banks and other institutions will no longer lend them money, they turn to the IMF to help them balance their payments with the rest of 
the world. The IMF initially focused on Europe, but by the 1970s, it turned its attention to the less developed economies. By the early 1980s, a large number of developing countries were having trouble financing their foreign debts (Stigbitz, 2003).

The IMF and the World Bank usually impose certain conditions for loans and require borrowers to set up what are called structural adjustment programs. These programs amount to detailed instructions on what countries have to do to bring their economies under control. The programs are based on a strategy called neoliberalism, also known as the Washington Consensus because both the IMF and the World Bank are headquartered in Washington DC. The strategy is geared toward promoting free markets by means of privatization (the selling off of government enterprises), deregulation (the elimination of rules that restrict companies), and trade liberalization (the opening up of local markets to foreign goods by removing barriers to export and imports) and also calls for shrinking of the role of government, reducing taxes, and cutting back on publicly provided services (Tabb, 2009).

Onwah Kuyo, the former director of budget and planning in the Ministry of Finance, observed in 2002 that the massive and ongoing devaluation of the naira, the excessive mopping up of liquidity by the Central Bank of Nigeria, the liberalization of trade that has permitted the importation of all manner of goods without regulation, the privatization of all major government corporations except those bought by Nigerians, and other measures that stem from policy prescriptions of the IMF will not move the nation forward. At that time, he urged the federal government to critically evaluate the advice of IMF, to accept those found consistent with Nigeria's restructuring program, and ignore the rest (Komolafe (2002).

John Perkins explains the negative role of "economic hit men" (EHMs) in the globalization process. EHMs are highly paid professional who cheat countries around the globe out of trillions of dollars. They funnel money from the World Bank, the U.S Agency for International Development (USAID), and other foreign 'aid' organizations into the coffers of huge corporations and the pockets of a few wealthy families who control the planet's natural resources. Their tools include fraudulent financial reports, election rigging, payoffs, extortion, sex, and murder. They play a game as old as empire, but one that has taken on new and terrifying dimensions during this time of globalization" (2004, p. ix). Perkins states further that American consulting firms would send their EHMs abroad to conduct economic and statistical analysis and to project growth based on cooked numbers and that these numbers are then invoked as reasons for extending large loans to the countries. Developmental works like power projects are then contracted to large American companies like Bechtel and Halliburton. These projects ensure that the loans granted are immediately ploughed back into American companies. The growth rate projected (sometimes as high as $20 \%$ ) cannot 
be achieved in a sustained fashion, and the countries thus end up bearing a high interest burden for the loan repayments (sometimes as high as $50 \%$ of national budgets).

Nwoye (n. d.) notes that given the fact that the initial impetus for privatization in Africa came from creditor's institutions, especially the IMF and the World Bank, as part of the push for structural adjustment, many believed that there must be a hidden agenda in the form of economic exploitation. As in other African countries, resentment in Nigeria has been intensified by the fact that a good number of the larger enterprises being privatized are bought up by foreign interests. Even if, it has been argued, privatization contributes to improved efficiency and financial performance, it has a negative effect on the distribution of wealth. Corruption no doubt plays a role in the unequal distribution of wealth. Corruption is the factor most responsible for the pitiable state of affairs in many developing countries. It distorts the economy through waste and misallocation of resources and creates need for external assistance. This is not to say that privatization in all its ramifications is harmful; even as Nwoye (n. d.) points out, if privatization is carried out with a sincerity of purpose, almost every group will come out ahead as a result of divestiture. Workers will be shareholders, and consumers will be better off because they will be offered better goods and services. New graduates and the unemployed will get jobs because of expansion. Government will be relieved of the burden of subsidies, and investors will gain investment opportunities. But at present the question is how serious and genuine the intentions of the government are with respect to privatization in Nigeria.

As Ogbuaku et al. note,

the process of globalization entails significant risks and enormous economic and social cost. Openness to global markets can expose domestic financial markets to greater volatility, which could be more severe in countries with weak financial systems and economic policies lacking credibility. In this context, large reversals in short-term capital flows have led to severe financial crises and sharp increases in unemployment and poverty in the short run. The United Nations Human Development Report . . [2001] indicates that while GDP per person in industrialized countries rose from $\$ 6,500$ in 1960 to $\$ 16,750$ in 1998 , the least developed countries remained at $\$ 750$. So, the rich-poor gap increased by $\$ 10,250$ per person during that period. According to the report, while in the decade and a half before 1980, developing countries experienced a higher rate of income growth than developed countries, since 1980, this pattern has reversed. In Africa, South of the Sahara, $25 \%$ of the people, corresponding to 340 million people live in less than $\$ 1.00$ (dollar)a day. With increased globalization, Africa's share of world trade in general and raw materials in particular has been declining during the last twenty years. Africa's average share of world exports dropped from 5.3\% (1960-69) to $1.5 \%$ (1999). In 1970 , the $\$ 1 /$ day poverty rate $(22.2 \%)$ was very 
similar to that of Asia (22.4\%). By 1998, however, the African rate almost doubled to $40.5 \%$ whereas the Asian's has almost disappeared (1.7\%). In the same context, the number of poor people increased by 17.5 million over the entire period ( 22.8 million in the 1970s, 51.7 million in the 1980s and 101 million in the 1990s). One of the largest increases (56 million) was recorded in Nigeria because of its large population. It is estimated that about $70 \%$ or 80 million Nigerians live on less than \$1 per day (Sala-i-Martin, 2002). (2006, pp. 63-64)

Ogbuaku et al. further state that "the UNDP Human Development Index (HDI) ranked Nigeria as 142nd with an HDI of 0.400 among the 174 countries listed in 1997. By 1998, the country dropped to 146th position and fell among the 40 poorest countries. The incidence of poverty has been high and on the increase since 1980. Data from the Federal Office of Statistics (FOS) on poverty profile in Nigeria showed that the incidence of poverty rose from $28.1 \%$ in 1980 to $43.6 \%$ in 1985 , but dropped slightly to $42.7 \%$ in 1992 from where it rose sharply to $65.6 \%$ in 1996 and steadily rose to $70.2 \%$ in 2003" (2006, p. 65). In 2007, Nigeria's HDI was ranked by the United Nations as 157th out of 177 countries (Azeez, 2010), and In 2013, its HDI was ranked 153rd out of 186. Countries like Angola, Burundi, the Democratic Republic of the Congo, Ethiopia, Liberia, Mali, Mozambique, Niger, Rwanda, Sierra Leone, and Tanzania are among the African countries that have made the greatest strides in HDI improvement since 2000. Life expectancy in Nigeria is 52 years, and other health indicators reveal that only $1.9 \%$ of the nation's budget is expended on health. The adult illiteracy rate (both sexes) in Nigeria is $61.3 \%$, and $68.0 \%$ of Nigerians are stated to be living below US\$1.25 daily poverty level. According to Udo (2013), the UN's HDI was released at a time of reported growth in the Nigerian economy, with the country recording a GDP growth rate of $6.99 \%$ in the fourth quarter of 2012. The country's economy has been described as robust and resilient, but this highly touted growth in the Nigerian economy has failed to have an impact on the lives of the citizenry, which gives credibility to the UN's HDI raises questions as to the authenticity of Nigeria's economic ratings.

To what extent the rising incidence of poverty in Nigeria since the 1980s is a direct consequence of globalization rather than internal factors such as the high rate of corruption is an open question, although the two are likely connected to the extent that global capital plays a role in corruption Nigeria.

Deardorff \& Stern, (2002) note that foreign investment can be beneficial for the economy in the long run. What is apparent however, is the existence of losers and gainers in the process. While foreign investment has the capacity to enrich a minority of countries or people who direct the process, a host of others are left behind, further marginalized, or even become more insolvent. Onwuka and Eguavoen observe that 
"Nigeria has not benefited from globalization due to monocultural export, inability to attract increased foreign investment, and huge indebtedness. But globalization can be domesticated in the country through diversification of exports, debt reduction and expanded development cooperation with other countries. The Nigerian state also needs to be strengthened as a bulwark against the dictates of foreign capital" $(2007,45)$. "Globalization," Onwuka and Eguavoen further argue, "can be of immense benefit to Nigeria and so could help the country's development. The enabling framework would include measures to ensure the entry of Nigeria's non-oil exports into the core markets without discrimination. In this regard, the diversification of domestic production is imperative" (2007, 50). At the same time, expanded cooperation with the developed world would help strengthen the country's economic productive base (Okoh, 2004; Ezike \& Ogege, 2012). In addition, in order for Nigeria to be integrated into the global economy, it must develop microeconomic and structural policies that allow it to be competitive in terms of the resources it offers for trade (Avarenren, 2001; Allege \& Ogun, 2004).

\section{CONCLUSION AND RECOMMENDATIONS}

Globalization has not yielded very positive results for the Nigerian economy, although it is true that there are other forces impeding significant economic growth. The activities of multinational corporations cannot be overlooked, as evidence of the devastating effects they have on the environment are glaring. The mode of operation of the two world financial institutions, the IMF and the Word bank, has not supported Nigeria's economic growth; in particular, the structural adjustment programs introduced by the IMF and adopted in 1986 by the federal government headed by General Babangida has been harmful to the country's economic well-being.

In view of the advantages and disadvantages of globalization and by extension global capital for the Nigerian economy, it can equally be argued that the demerits far outweigh the merits. Dependent states should therefore, attempt to pursue policies of self-reliance that would allow them to control interactions with the world economy and to engage in them only if they would improve the social and economic welfare of the larger citizenry. On this dependency theory view, Nigeria ought to, according to Esidene and Hafsat, "'delink' from the shackles of imperialist domination, develop its local technology, manage its own affairs, and drive the economy to greater pedestals of development" (2012, p. 17). Nigeria should thus embark on a strategic integration with the world market and determine the level at which to liberalize its economy, the type of cooperation and competition to engage in to stimulate and develop relationships 
between its local firms and foreign firms, and the particular sectors of the economy that need to be protected in order to encourage economic growth. In this regard, Nigeria should promote domestic industry and manufacture goods for export rather than simply exporting raw materials, limit the importation of luxury and manufactured goods that can be produced within the country in order to reduce loss of capital and resources, and take drastic steps to keep foreign companies and individuals from owning or operating property that draws on the resources of the country. Nigeria should also collaborate with regional bodies such as the African Union and Economic Community of West African States to form strategies for economic cooperation and integration that would engender socioeconomic development that is domestically oriented.

Above all, Nigeria and other African nations, according to Akindele et al. (2002: $\mathrm{n}$. pag), must respond to their own developmental needs "by rebuilding their national images, by fighting corruption, and by insisting on their own cultural preferences. ... This will only be possible through a sincere, committed, sociological, cultural, economic and political realignment that is truly African in nature and intent."

\section{REFERENCES}

Abimbola, J. O., \& A. G. Aremo. 2002. Globalization and poverty reduction in a democratic Nigeria. Ibadan: Social Studies Educationists Association of Nigeria Press.

Ajayi, S. I. 2001. What Africa needs to do to benefit from globalization, finance and development. Finance and Development, 38 (4): 6.

Akindele, S. T., T. O. Gidado, \& O. R. Olaopo. 2002. Globalisation: Its implications and consequences for Africa. Postcolonial Web. Retrieved on December 28, 2014, from http://www.postcolonialweb.org/africa/akindelele.html.

Akinboye, S. 2008. Globalization and the challenge for Nigeria's development in the 21st century. Retrieved on December 26, 2014, from http://globalization.icaap. org/content/v7.1/Akinboye.html.

Allege, P. O., \& T. P. Ogun. 2004. Exploring the globalization-industrialization nexus for economic development: A case of Nigeria. In Proceedings of the annual conference of the Nigerian Economic Society (pp. 45-274). Ibadan: Nigerian Economic Society.

Amin, S. 1971. Underdevelopment and dependence in black Africa: Historical origin. Journal of Peace Research, 9(2): 81-117.

Arghiri, E. 1972. Unequal exchange: A study of the imperialism of trade. New York: Monthly Review Press. 
Avarenren, K. 2001. Nigeria in the global economy. Nigerian Observer (Benin City), July 8.

Azeez, A. 2010. Good governance and democratic consolidation in Nigeria. Paper presented before the Faculty of the Social Sciences, University of Ibadan, October 2010.

Babawale, T. 2007. The political economy of development, governance and globalization. Vol. 1 of Nigeria in the crises of governance and development: A retrospective and prospective analysis of selected issues and events. Lagos: Political and Administrative Resource Centre.

Bauman, Z. 1998. Globalization: The human consequences. Cambridge, UK: Polity Press.

Beck, U. 1992. Risk society: Towards new modernity. London: Sage.

Beck, U. 2006. Cosmopolitan vision. Cambridge, UK: Polity Press.

Biersterker, T. J. 1998. Globalization and the models of operation of major institutional actors. Oxford Development Studies, 26(1): 15-31.

Central Bank of Nigeria. 2000. Foreign private investment in Nigeria-1998. CBN Economic Financial Review, 38(2): 579.

Cerny, P. G., \& Evans, M. 2004. Globalisation and public policy under New Labour. Policy Studies, 25(1): 51-65.

Chiakwelu, E. 2008. Nigeria's foreign debts payments reflect devastating transfer of wealth US African online. Retrieved on December 31, 2014 from: http://www. usafricaonline.com/nigeriadebts06.echiakwelu.html

Chilcote, R. H. 1984. Theories of development and underdevelopment. Boulder, CO: Westview Press.

Chilcote, R. H. 2002. Globalization or imperialism? Latin American Perspectives, 29(6): 80-84.

Cohn, T. H. 2005. Global political economy: Theory and practice. New York: Longman.

Collier, P., \& D. Dollar. 2001. Globalization, growth and prosperity: Building an inclusive world economy. Oxford: Oxford University Press.

Crouch, C. 2004. Post-democracy. Cambridge, UK: Polity Press.

Dani, R. 1999. The new global economic and the developing countries: Making openness work. Baltimore, MD: John Hopkins University Press.

Daouas, M. 2001. Africa faces the challenge of globalization. Finance and Development, 38(4): 4- 5

David, V. 1999. Barriers or benefits? Regulation in transatlantic trade. Washington, DC: Brookings Institute Press.

Deardorff, A. V. and Stern, R. M. 2002. What You should know about Globalization 
and The World Trade Organization. Review of International economics, 10 (3): 404-423, Retrieved on December 31, 2014, from http://isites.harvard.edu/fs/ docs/icb.topic192642.files/Folder02/DeardorffStern2002.pdf.

Diagne, S. N. O. 1996. The cultural question in Africa: Issues, politics and research prospects. Working paper 3, CODESRIA. Retrieved on December 26, 2014, from http://www.codesria.org/spip.php?article1062.

Doguwa, S. I. E. 2000. Measuring the economic impact of the federal government budget, 1995-2000. Economic and Financial Review, 38(3): 1-32.

Egonmwan, J. A. 1991. Public policy analysis: Concepts and application. Benin City: Ambik Press.

Esidene, E. C., \& K. Hafsat. 2012. Globalization, multinational corporation and the Nigerian economy. International Journal of Social Science Tomorrow, 1(2): 1-17.

Ezike, J. E., \& S. Ogege. 2012. Nigeria foreign trade policy: Its impact on non-oil exports. Journal of Economics and International Finance, 4(8): 192-200.

Frank, A. G. 1969. Capitalism and underdevelopment in Latin America. New York: Monthly Review Press

Frank, A. G. 1970. Latin America: Underdevelopment or revolution. New York: Monthly Review Press.

Fukuyama, F. 1989. The end of history? National Interest, 16 (3): 3-18.

Fukuyama, F. 1992. The end of history and the last man. Harmondsworth, UK: Penguin.

Galtung, J. 1972. Structural theory of imperialism. African Review, 1(4): 93-138.

Garry, B. 1998. Globalization: Confronting fear about open trade. Washington, DC: Brookings Institute Press.

Gill, S. 2000. Towards a postmodern prince? The battle in Seattle as a moment in the new politics of globalisation. Millennium: Journal of International Studies, 29 (1): 131-140.

Gray, J. 1996. After social democracy: Politics, capitalism and the common life. London: Demos.

Grieco, M., \& L. Holmes. 1999. Tele-options for community business: An opportunity for economic growth in Africa. Africa Notes (October): 1-3.

Hagher, I. 2002. Leading Africa out of chaos: A God-centered approach to leadership. Ibadan: Spectrum Books.

Halsall, P. 1997. Modern history sourcebook: Summary of Wallerstein on world system theory. Retrieved on December 26, 2014, from http://legacy.fordham.edu/halsall/ $\mathrm{mod} /$ Wallerstein.asp.

Held, D., A. McGrew, D. Goldblatt, \& J. Perraton. 1999. Global transformations: Politics, economics and culture. Cambridge, UK: Polity. 
Heywood, A. 2007. Politics. 3rd ed. Basingstoke, UK: Palgrave Macmillan.

Hoogvelt, A. 2001. Globalization and the postcolonial world: The new political economy of development. London: Palgrave Macmillan.

IMF. 2002. Globalization: Threat or opportunity? Retrieved on September 1, 2014, from www.imf.org/external/np/exr/ib/2006/041200.htm.

Kaplinksy, R. 2005. Globalization, poverty and inequality. Cambridge, UK: Polity Press.

Keane, J. 2003. Global Civil Society. Cambridge: Polity Press.

Khor, M. 2000. Globalization and the South: Some critical issues. Ibadan: Spectrum Books.

Komolafe, B. 2002. IMF policies are not good for Nigeria, says ex-director of budget and planning. Vanguard, July 30.

Lechner, F. 2001. Globalization theories: World-system theory. The Globalization Website. Retrieved on December 26, 2014, from http://sociology.emory.edu /faculty/globalization/theories.html.

Mackay, H. 2000. The globalization of culture? In D. Held (ed.), A globalizing world? Culture, economics, politics (pp. 47-84). London: Routledge

Madunagu, E. 1999. Globalization and its victims. Guardian, July 26, 53.

Marfleet, P. 1998. Globalization and the third world. International Socialism Journal, 81(2): 91-130.

McMichael, P. 2000. Development and social change: A global perspective. Thousand Oaks, CA: Pine Forge Press.

Mittelman, J. 2006. Globalization and its critics. In R. Stubs \& G. Underhill (eds.), Political economy and the changing global order (pp. 64-76). Oxford: Oxford University Press.

Nayyar, D. 2006. Globalization, history, and development: A tale of two centuries. Cambridge Journal of Economics, 30(1): 137-159.

Nederveen, P. J. 2004. Globalization and culture: Global mélange. Lanham, MD: Rowman and Littlefield.

Nwoye, M. n.d. Privatization of public enterprises in Nigeria: The views and counterviews. Journal for Political Theory and Research on Globalization, Development and Gender Issues. Retrieved on December 26, 2014, from www.globalizacija. com/doc_en/e0062pri.htm.

Obadan, M.I. 2001. Africa and the challenges of globalization: How should the continent respond? Nigerian Economic and Financial Review, 6(2): 12-19.

Obadina, T. 1998. Globalization, human rights and development. Africa Today, October, 32-33.

Ogbuaku, H. G., A. Adebisi, \& M. Feridun. 2006. Does globalization lead to increased 
poverty? Empirical evidence from Nigeria. Economia internazionale, 59: 63 Ohiorhenuan, J. F. E. 1998. The South in an era of globalization. Cooperation South, 2: 6-15.

Okoh, R. N. 2004. Globalization and growth of Nigerian non-oil exports. Paper presented at the Centre for the Study of African Economies, African Conference on Growth, Poverty Reduction and Human Development in Africa, March 21-22, Oxford, UK.

Okonjo-Iweala N. 2007. Nigeria's fight for debt relief: Tracing the path. Retrieved on December 31, 2014 from: http://www.brookings.edu/ /media/Events/2007/8/01 sustainable\%20development/2007okonjoiweala.pdf.

Onwuka, E. C., \& A. Eguavoen. 2007. Globalization and economic development: The Nigerian Experience. Journal of Social Science, 14(1): 45-51.

O'Rourke, K. H., \& J. G. Williamson. 2000. Globalization and history. Cambridge, MA: MIT Press.

Perkins, J. 2004. Confessions of an economic hit man. San Francisco: Berrett-Koehler. Peter, O. N. 2002. Economic restriction through privatization. Economist, 4: 32-34.

Rapley, J. 2004. Globalization and inequality: Neoliberalism's downward spiral. Boulder, CO: Lynne Rienner.

Rodrik, D. 2000. Comments on "Trade, Growth and Poverty" by D. Dollar and A. Kraay. Retrieved on October 1, 2014, from http://ksghome.harvard.edu/ drodrik/ Rodrik\%20on\%20Dollar-Kraay.PDF.

Sala-I-Martin, X. 2002. The world distribution of income (estimated from individual distributions). INBER Working Paper Series 8933.

Salimono, A. 1999. Globalization and challenges. Paper presented at the International Summit on Globalization, January 18-22, Havana, Cuba.

Scholte, J. A. 2000. Globalization: A critical introduction. Basingstoke, UK: Palgrave Macmillan.

Scholte, J. A. 2005. Globalization: A critical introduction. 2nd ed. Basingstoke, UK: Palgrave.

Sklair, L. 2002. Globalization: Capitalism and its alternatives. Oxford: Oxford University Press.

Strange, S. 1996. The retreat of the state: The diffusion of power in the world economy. Cambridge: Cambridge University Press.

Sunkel, O. 1969. National development policy and external dependence in Latin America. Journal of Development Studies, 6 (1): 23-48.

Tabb, W. K. 2008. Globalization. Microsoft Encarta (DVD). Redround, WA: Microsoft Corporation.

Tandon, Y. 1998b. Globalization and Africa's options. Pt. 2. AAPS Newsletter, 3(2) 
May-August

Tomlinson, J. 1999. Globalization and culture. Cambridge, UK: Polity Press.

Udo, B. 2013. Nigeria's human development index growth not as high as others in sub-Saharan Africa-UNDP. Premium Times, March 14. Retrieved on April 4, 2014, from www.premiumtimes.com/124844/nga.

United Nations (UN). 2001. World economic and social survey 2001: Trends and policies in the world economy. In Human Development Report 2001. Retrieved on November 2, 2014, from www.undp.org/hdr.

United Nations Conference on Trade and Development (UNCTAD). 2001b. World investment report 2001: Promoting linkages. New York and Geneva: United Nations.

United Nations Conference on Trade and Development (UNCTAD). 2002a. World investment report 2002: Transnational corporations and export competitiveness. Geneva: United Nations.

United Nations Conference on Trade and Development (UNCTAD). 2002b. UNCTAD Handbook of Statistics 2002. Geneva: United Nations.

United Nations Conference on Trade and Development (UNCTAD). 2003. Trade and development report 2003: Capital accumulation and structural change. Geneva: United Nations.

United Nations Conference on Trade and Development (UNCTAD). 2012. World investment report overview. Retrieved on October 14, 2014, from http://unctad. org/en/PublicationsLibrary/wir2012overview_en.pdf.

United Nations Conference on Trade and Development (UNCTAD). 2013. IntraAfrican trade: Unlocking private sector dynamism. Retrieved on October 14, 2014, from http://unctad.org/en/PublicationsLibrary/aldcafrica2013_en.pdf.

United Nations Development Programme (UNDP). 2013. The rise of the South: Human progress in a diverse world. Retrieved on November 2, 2014, from www.undp. org/en/statistics/hdi.

Urry, J. 2000. Sociology beyond societies: Mobilities for the twenty-first century. London: Routledge.

Wallerstein, I. 1973. Dependency in an interdependent world: The limited possibilities of transformation within the world's capitalist economy. Paper presented at the Conference on Dependence and Development in Africa, February 6-18, Ottawa, Canada.

Wallerstein, I. 2003. The decline of American power: The U.S. in a chaotic world. New York: New Press.

Wallerstein, I. 2005. World-systems analysis: An introduction. Durham, NC: Duke University Press. 
Wikipedia, 2013. Economy of Nigeria: The World Bank Economic Report on Nigeria. Retrieved on December 31, 2014 from http://en.wikipedia.org/wiki/Economy_ of_Nigeria.

Wolf, M., \& R. Wade. 2002. Are global poverty and inequality getting worse? Prospect, 72 (March): 16-21.

World Bank. 2002. Globalization, growth and poverty: A World Bank policy research report. Washington, DC: World Bank.

World Bank. 2014. Foreign direct investment flows into sub-Saharan Africa. Retrieved on October 15, 2014, from wwwwds.worldbank.org/external/default/WDS ContentServer/WDSP/IB/2014/03/18/000456286_20140318105721/Rendered/ PDF/860600BRI0WB0H00Box382147B00PUBLIC0.pdf.

Zuma, N. D. 2003. NEPAD's peer review mechanism. Retrieved on November 2, 2014, from http://www.sarpn.org/documents/d0000564. 